\title{
Organogenesis Dua Tipe Mengkudu (Morinda citrifolia L.) Pada Berbagai Kombinasi Konsentrasi IAA (Indole Acetid Acid) dan BAP (Benzil Amino Purin) secara in vitro
}

\section{(Organogenesis Two Types Noni (Morinda citrifolia L.) In Different Combination Of Concentration IAA (Indole Acetid Acid) and BAP (Benzyl Amino Purine) for in vitro)}

\author{
Putri Suria Ningsi $^{\left.1^{*}\right)}$, Muslimin $^{2}$, I Nengah Suwastika $^{1}$ \\ ${ }^{1}$ Lab. Biotekhnologi Jurusan Biologi Fakultas MIPA, UniversitasTadulako \\ ${ }^{2}$ Lab. Kultur Jaringan FakultasKehutanan, UniversitasTadulako
}

\begin{abstract}
The aims of this research were to determine the growth rate of organogenesis Noni (Morinda citrifolia L.) with big fruit type and the type of small fruit which grown in vitro, and also knowing the combination of the concentration of growth regulators that either promotes the growth of two types of Noni. The explants used were sterile seedling of both types of Noni. This experiment was arranged based on Completely Randomized Design (CRD) with five treatments and three repetitions. Treatments were concentration of growth hormones on MS (Murashige dan Skoog) medium i.e. 0.3 ppm BAP in combination to various concentration of IAA ( $0 \mathrm{ppm} ; 0.05 \mathrm{ppm} ; 0.5 \mathrm{ppm} ; 0.7 \mathrm{ppm}$; and $0.9 \mathrm{ppm})$. Observed Parameters were period of roots and leaves initiation, the number of roots and leaves, and chlorophyll content. The result showed that P2 medium $\left(\mathrm{MS}_{0}+0.05 \mathrm{ppm}\right.$ IAA + $0.3 \mathrm{ppm}$ BAP) was the best medium in shootinitiation for both Nonis. While P5 medium $\left(\mathrm{MS}_{0}+0.9 \mathrm{ppm} \mathrm{IAA}+0.3 \mathrm{ppm}\right.$ BAP $)$ was suitable in induction of root growth.
\end{abstract}

Key words : $\quad$ Organogenesis, MS medium, IAA, BAP, Morinda citrifolia L.

\begin{abstract}
ABSTRAK
Penelitian ini bertujuan untuk mengetahui laju pertumbuhan organogenesis mengkudu (Morinda citrifolia L.) dengan tipe buah besar dan tipe buah kecil yang ditumbuhkan secara in vitro, dan mengetahui kombinasi konsentrasi zat pengatur tumbuh yang baik untuk mendorong pertumbuhan dua tipe mengkudu. Eksplan yang digunakan adalah kecambah steril dari kedua tipe mengkudu. Penelitian ini disusun berdasarkan Rancangan Acak Lengkap (RAL) dengan 5 perlakuan dan 3 ulangan. Media perlakuan yang digunakan adalah media MS (Murashige dan Skoog) dengan penambahan 0,3 ppm BAP (Benzil Amino Purin) dan penambahan konsentrasi IAA (Indole Acetid Acid) yang berbeda ( 0 ppm ; 0,05 ppm ; 0,5
\end{abstract}


ppm ; 0,7 ppm ; dan 0,9 ppm). Parameter pengamatan meliputi saat muncul daun dan akar, jumlah daun dan akar, dan kadar klorofil. Hasil penelitian menunjukkan bahwa media perlakuan terbaik untuk mendorong pertumbuhan daun kedua tipe mengkudu yaitu media P2 $\left(\mathrm{MS}_{0}+0,05 \mathrm{ppm}\right.$ IAA $+0,3 \mathrm{ppm}$ BAP), sedangkan media yang paling baik dalam mendorong pembentukan akar yaitu media P5 $\left(\mathrm{MS}_{0}+0,9 \mathrm{ppm}\right.$ IAA + 0,3 ppm BAP).

\section{Kata kunci : Organogenesis, Media MS, IAA, BAP, Morinda citrifolia L.}

\section{LATAR BELAKANG}

Mengkudu (Morinda citrifolia L.) merupakan salah satu jenis tanaman yang digunakan sebagai bahan obat herbal dan dalam beberapa tahun terakhir ini banyak peminatnya baik dari kalangan pengusaha agribisnis, maupun dari kalangan pengusaha industri obat tradisional, bahkan dari kalangan ilmuwan di berbagai Negara (Djauhariya dan Rosman, 2001). Mengkudu merupakan tanaman tropis dan liar, yang dapat tumbuh di tepi pantai hingga ketinggian $1500 \mathrm{~m}$ dpl (di atas permukaan laut). Penyebarannya cukup luas, meliputi seluruh kepulauan Pasifik Selatan, Malaysia, Indonesia, Taiwan, Filipina, Vietnam, India, Afrika, dan Hindia Barat (Solomon, 1999 ; Djauhariya dkk., 2006).

Pemanfaatan mengkudu sebagai obat tradisional sebenarnya sudah ada sejak lama (Djauhariya dkk., 2006). Tidak hanya di Indonesia, masyarakat Asia pun mempercayai bahwa secara tradisional mengkudu dapat mengobati berbagai penyakit (Anggraeni dkk., 2007). Manfaat mengkudu dalam pengobatan tradisional mendorong para peneliti di berbagai belahan dunia melakukan berbagai penelitian mengenai khasiat mengkudu (Djauhariya dan Rosman, 2001). Zat kimia yang terkandung, di antaranya adalah damnacanthal, xeronin, morindin, antraquinon, asam glutamat, asam askorbat, thiamin, glikosida dan skopoletin. Zat nutrisi yang terkandung dalam mengkudu di antaranya protein, mineral, vitamin yang berkhasiat sebagai antioksidan (Bangun dan Sarwono, 2002).

Selama ini industri obat tradisional yang mengolah buah mengkudu belum diimbangi dengan upaya pengembangan budidaya yang memadai (Djauhariya dan Rosman, 2001). Khususnya di daerah Palu budidaya mengkudu masih terbilang kurang, sehingga untuk mencukupi permintaan perusahaan industri akan buahbuah mengkudu yang akan diekspor masih diperoleh dari tanaman liar. Oleh karena itu, diperlukan cara lain untuk menghasilkan bahan obat herbal, salah satunya yaitu melalui bioteknologi.

Salah satu teknik dalam bioteknologi yang diharapkan dapat digunakan adalah 
teknologi kultur jaringan. Menurut Radji (2005), teknologi kultur jaringan sangat penting dilakukan untuk menghindari kelangkaan bahan baku obat herbal yang sampai saat ini masih diambil dari tanaman aslinya. Regenerasi tanaman dengan teknik kultur jaringan ini terbukti menghasilkan bahan kimia yang sama dengan tanaman induknya. Gunawan (1992) menyatakan bahwa teknik kultur jaringan juga mampu menghasilkan tanaman dalam jumlah yang besar dengan waktu yang relatif singkat serta dengan kualitas tanaman yang dihasilkan menjadi lebih baik.

Survei awal yang dilakukan di lembah Palu ditemukan beberapa tipe mengkudu yang memiliki ukuran buah yang berbeda, di antaranya ada yang berukuran sangat kecil dengan panjang 2-3 cm dan diameter 2-4 cm, ada pula yang berukuran besar dengan panjang 9-12 $\mathrm{cm}$ dan diameter 4-6 cm. Sejauh ini mengkudu yang memiliki buah yang berukuran sangat kecil masih belum ada yang memanfaatkan dibandingkan dengan mengkudu yang memiliki buah yang berukuran besar.

Selain tersebut di atas, penggunaan bagian tanaman mengkudu dalam penelitian kultur jaringan belum banyak dilaporkan. Oleh karena itu untuk mengembangkan bioteknologi dalam bidang ini, maka dilakukan penelitian mengenai pertumbuhan dua tipe mengkudu tersebut melalui tahap organogenesis secara in vitro.

Tujuan dari penelitian ini yaitu untuk mengetahui laju organogenesis mengkudu dengan tipe buah besar dan tipe buah kecil yang ditumbuhkan secara in vitro, dan mengetahui kombinasi konsentrasi zat pengatur tumbuh yang baik untuk mendorong pertumbuhan dua tipe mengkudu.

\section{BAHAN DAN METODE}

Penelitian ini dilaksanakan pada bulan Februari sampai bulan September 2015 di Laboratorium Kultur Jaringan Fakultas Kehutanan Universitas Tadulako dan Laboratorium Bioteknologi, Jurusan Biologi, Fakultas Matematika dan Ilmu Pengetahuan Alam, Universitas Tadulako. Penelitian ini bersifat eksperimen dengan menggunakan rancangan acak lengkap (RAL) dengan penambahan zat pengatur tumbuh Indole Acetid Acid (IAA) dan Benzil Amino Purin (BAP). Masing-masing tipe mengkudu ditanam di dalam botol kultur dengan perlakuan sebagai berikut:

1. $\mathrm{P} 1=\mathrm{MS}_{0}+0$ ppm IAA $+0,3$ ppm BAP

2. $\mathrm{P} 2=\mathrm{MS}_{0}+0,05 \mathrm{ppm} \mathrm{IAA}+0,3 \mathrm{ppm}$ BAP

3. $\mathrm{P} 3=\mathrm{MS}_{0}+0,5$ ppm IAA $+0,3$ ppm BAP

4. $\mathrm{P} 4=\mathrm{MS}_{0}+0,7 \mathrm{ppm} \mathrm{IAA}+0,3 \mathrm{ppm}$ BAP 
5. $\mathrm{P} 5=\mathrm{MS}_{0}+0,9$ ppm IAA $+0,3 \mathrm{ppm}$ BAP

Setiap perlakuan dilakukan 3 kali ulangan sehingga jumlah botol kultur yang digunakan untuk dua tipe mengkudu yaitu 30 botol. Jumlah eksplan yang ditanam pada tiap botol berisi 1 eksplan. Parameter yang diamati dalam penelitian ini yaitu (1) saat muncul daun dan akar, (2) jumlah daun dan akar (dihitung pada akhir pengamatan), dan (3) kadar klorofil (dihitung pada akhir pengamatan)

\section{HASIL DAN PEMBAHASAN}

Tahap awal dari penelitian ini yaitu tahap organogenesis pada tanaman mengkudu (Morinda citrifolia L.) secara in vitro. Tahap organogenesis ditandai dengan munculnya organ secara langsung, yaitu suatu proses pembentukan organ dari potongan tanaman tanpa didahului dengan terbentuknya kalus, seperti yang terlihat pada gambar a dan b. Hal ini ditunjukkan dengan terbentuknya akar dan daun yang berhasil diinduksi oleh semua media MS dengan penambahan zat pengatur tumbuh IAA dan BAP pada berbagai konsentrasi.

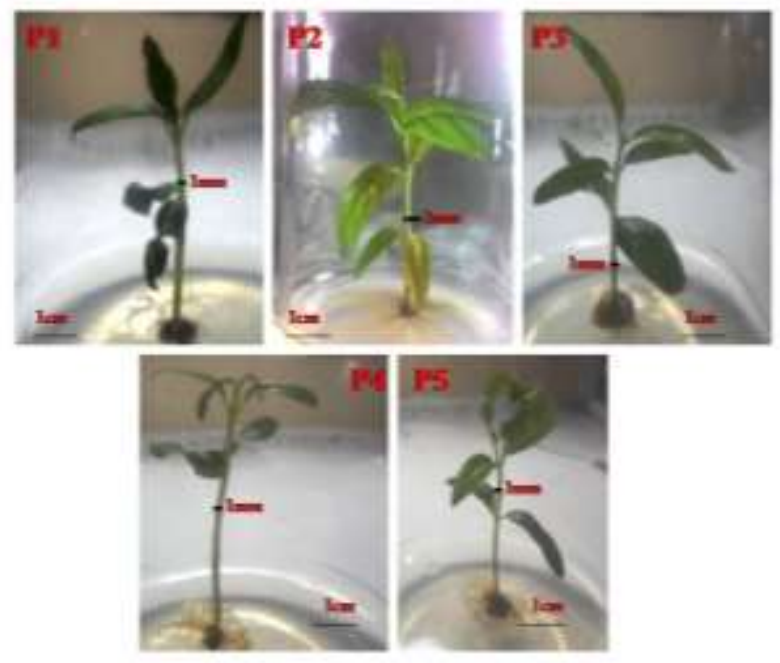

Gambar a. Hasil pengamatan kultur mengkudu besar.

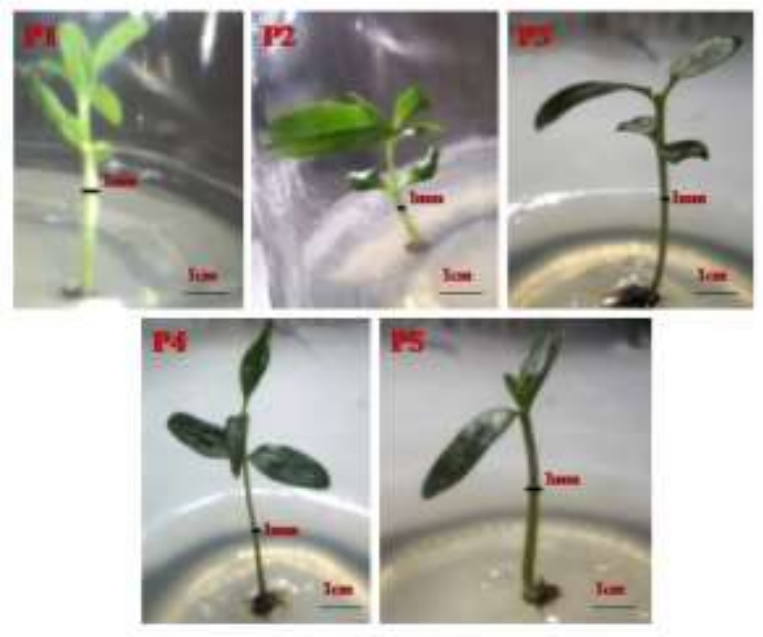

Gambar b. Hasil pengamatan kultur mengkudu kecil.

\section{Keterangan :}

P1 : $\mathrm{MS}_{0}+0$ ppm IAA $+0,3$ ppm BAP

$\mathrm{P} 2: \mathrm{MS}_{0}+0,05$ ppm IAA $+0,3$ ppm BAP

$\mathrm{P} 3: \mathrm{MS}_{0}+0,5 \mathrm{ppm} \mathrm{IAA}+0,3 \mathrm{ppm} \mathrm{BAP}$

$\mathrm{P} 4: \mathrm{MS}_{0}+0,7 \mathrm{ppm} \mathrm{IAA}+0,3 \mathrm{ppm}$ BAP

$\mathrm{P} 5: \mathrm{MS}_{0}+0,9 \mathrm{ppm}$ IAA $+0,3 \mathrm{ppm}$ BAP

Berdasarkan hasil penelitian menunjukkan bahwa semua perlakuan yang diujikan mampu mendorong organogenesis tanaman mengkudu secara in vitro, yang ditandai dengan terbentuknya akar dan daun pada eksplan yang ditanam, baik 
mengkudu dengan tipe buah yang besar maupun yang kecil. Tetapi organogenesis daun dan akar tanaman mengkudu tersebut tidak terbentuk secara bersamaan. Hal ini sesuai dengan pernyataan Altman dan Loberant (1998), bahwa pada proses organogenesis, eksplan akan menghasilkan tunas dan akar, namun keduanya tidak akan muncul bersamaan, biasanya tunas yang akan terbentuk lebih dulu. Pembentukan organogenesis tanaman mengkudu dapat dilakukan dengan dua tahap yaitu pada tahap pertama untuk menginduksi tajuk (daun dan batang) dan tahap kedua untuk mendorong pembentukan akar tanaman mengkudu.

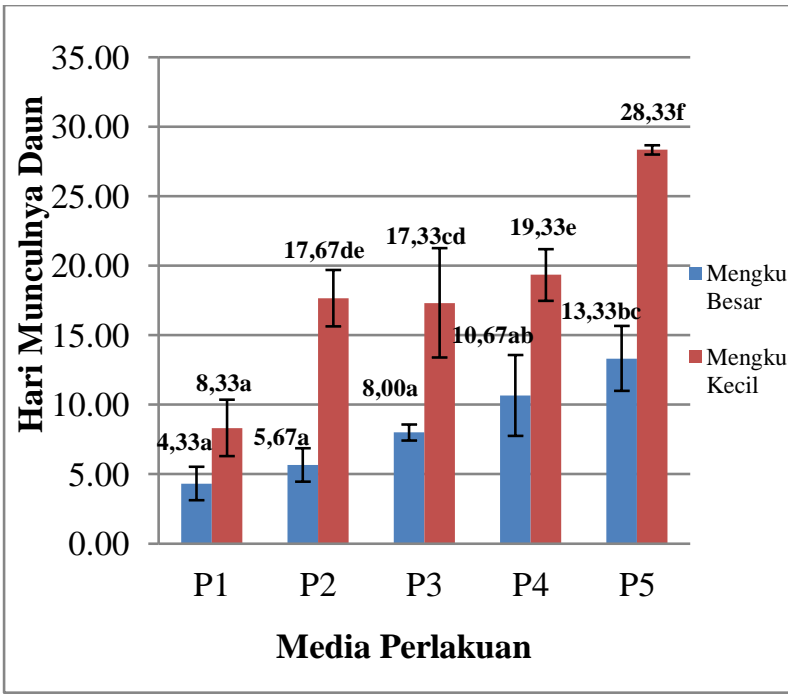

Gambar 1. Grafik rata-rata saat muncul daun dua tipe mengkudu. Angka diikuti dengan huruf yang menunjukan hasil Uji BNJ pada taraf $5 \%$.

Tahap pertama dapat menggunakan media P2 $\left(\mathrm{MS}_{0}+0,05 \mathrm{ppm}\right.$ IAA $+0,3 \mathrm{ppm}$ BAP) untuk menginduksi tajuk, karena media P2 merupakan media yang paling baik dalam mendorong pembentukan daun pada kedua tipe mengkudu tersebut dibandingkan dengan perlakuan yang lain, seperti yang terlihat pada gambar a dan b. Hal ini dapat dilihat dari hasil pengamatan jumlah daun yang terbentuk (Gambar 2). Meskipun media perlakuan yang pada awalnya cepat merespon pertumbuhan daun kedua tipe mengkudu tersebut yaitu media $\mathrm{P} 1\left(\mathrm{MS}_{0}+0\right.$ ppm IAA + 0,3 ppm BAP $)$, tetapi dilihat dari jumlah daun yang terbentuk hingga akhir pengamatan, media P2 ternyata lebih banyak merespon dengan pembentukan daun pada kedua tipe mengkudu tersebut, sehingga untuk menginduksi tajuk kedua tipe tanaman mengkudu sebaiknya menggunakan media perlakuan P2. Hasil ini sesuai dengan penelitian-penelitian sebelumnya dengan menggunakan tanaman yang berbeda. Tajuddin dkk. (2012) melaporkan bahwa kombinasi 0,1 ppm IAA dan 0,3 ppm BAP (B2) cenderung menghasilkan jumlah daun tanaman anggur yang paling banyak dibandingkan perlakuan yang lain dengan rata-rata 5,7 daun/eksplan. Hal ini juga sesuai dengan penelitian yang dilakukan oleh Harliana dkk. (2012) yang melaporkan bahwa jumlah tunas jeruk terbanyak diinduksi pada media perlakuan MS dengan penambahan 0,1 ppm IAA dan 0,4 BAP dengan rata-rata 1,33. Lebih lanjut 
Hartmann et al. (1997) menyatakan bahwa penggunaan sitokinin dengan konsentrasi yang tinggi dan auksin yang rendah sangat penting dalam pembentukan organ.

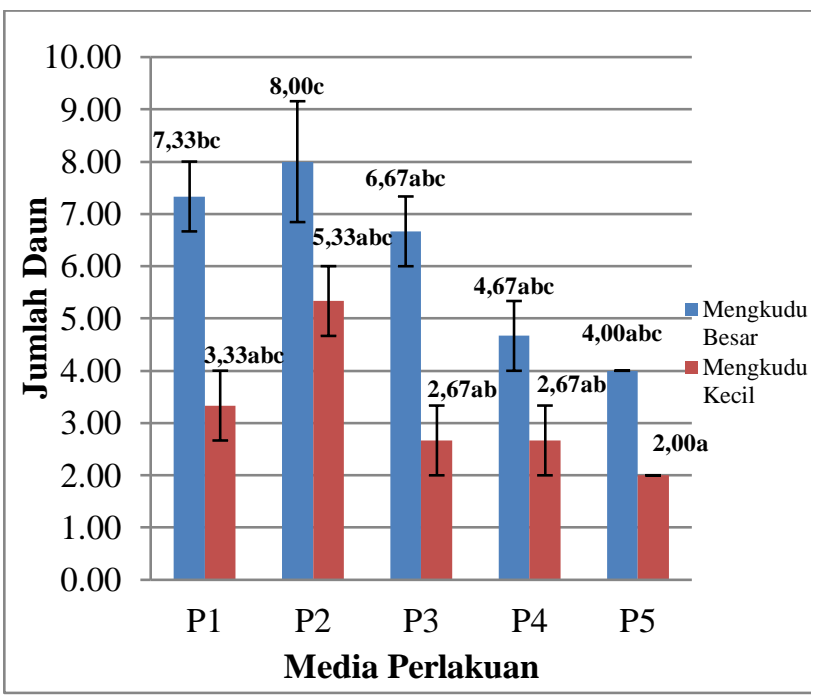

Gambar 2. Grafik rata-rata jumlah daun dua tipe mengkudu. Angka diikuti dengan huruf yang menunjukan hasil Uji BNJ pada taraf 5\%.

Tahap kedua dalam organogenesis mengkudu yaitu dalam pembentukan akar dapat dilakukan dengan menggunakan media P5 $\left(\mathrm{MS}_{0}+0,9 \mathrm{ppm} \mathrm{IAA}+0,3 \mathrm{ppm}\right.$ BAP). Media P5 merupakan media yang paling baik dalam mendorong pembentukan akar dibandingkan dengan perlakuan yang lain, seperti yang terlihat pada gambar c dan d. Hal ini dapat dilihat dari hasil akhir pengamatan jumlah akar (Gambar 4). Pada pengamatan saat munculnya akar, pada tanaman mengkudu besar yang tercepat membentuk akar, terdapat pada media perlakuan P5, sedangkan pada tanaman mengkudu kecil terdapat pada media P3 (Gambar 4 dan 5). Hal ini kemungkinan terjadi karena setiap tanaman memiliki respon yang berbeda terhadap zat pengatur tumbuh yang diberikan, tetapi melihat hasil akhir dari pengamatan jumlah akar yang terbentuk ternyata media perlakuan P5 lebih banyak merespon pembentukan akar pada kedua tipe mengkudu tersebut, sehingga media perlakuan P5 lebih baik digunakan untuk tahap pembentukan akar tanaman mengkudu. Hasil ini tidak sesuai dengan penelitian yang dilakukan oleh Harliana dkk. (2012) yang menunjukkan bahwa hasil pengamatan pada media perlakuan MS dengan penambahan 1,0 ppm IAA dan 0,6 ppm BAP masih menginduksi tunas dan belum mampu menginduksi akar tanaman jeruk. Secara umum sesuai dengan pernyataan yang dikemukakan oleh Ayabe dan Sumi (1998), bahwa perbandingan konsentrasi auksin yang lebih tinggi dari sitokinin dapat menyebabkan terangsangnya pembentukan akar, sebaliknya bila konsentrasi sitokinin lebih tinggi dari auksin maka akan cenderung mendorong terbentuk pucuk (tunas).

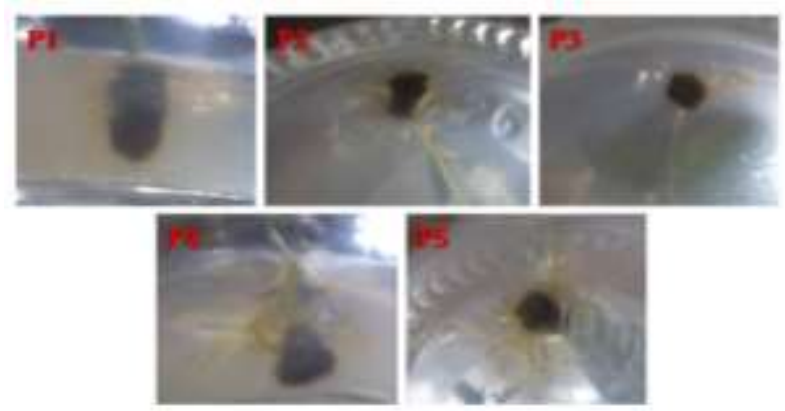

Gambar c. Hasil pengamatan akar mengkudu besar. 


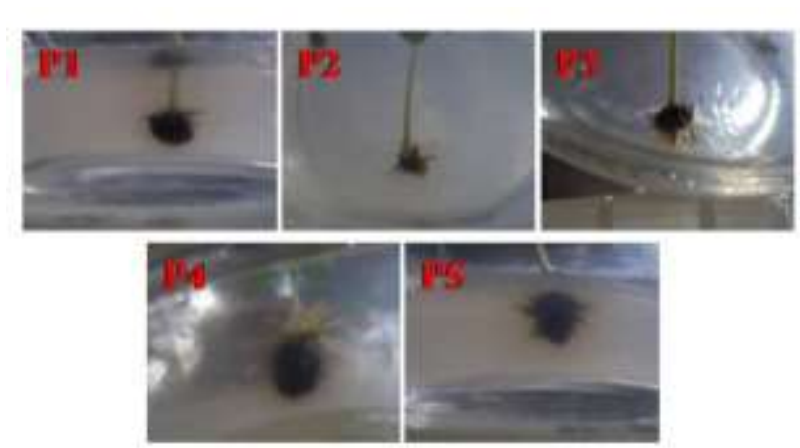

Gambar d. Hasil pengamatan akar mengkudu kecil

\section{Keterangan :}

$\mathrm{P} 1: \mathrm{MS}_{0}+0$ ppm IAA $+0,3$ ppm BAP $\mathrm{P} 2: \mathrm{MS}_{0}+0,05$ ppm IAA $+0,3$ ppm BAP

$\mathrm{P} 3: \mathrm{MS}_{0}+0,5 \mathrm{ppm} \mathrm{IAA}+0,3 \mathrm{ppm} \mathrm{BAP}$

$\mathrm{P} 4: \mathrm{MS}_{0}+0,7 \mathrm{ppm} \mathrm{IAA}+0,3 \mathrm{ppm} \mathrm{BAP}$

P5 : $\mathrm{MS}_{0}+0,9 \mathrm{ppm} \mathrm{IAA}+0,3 \mathrm{ppm} \mathrm{BAP}$

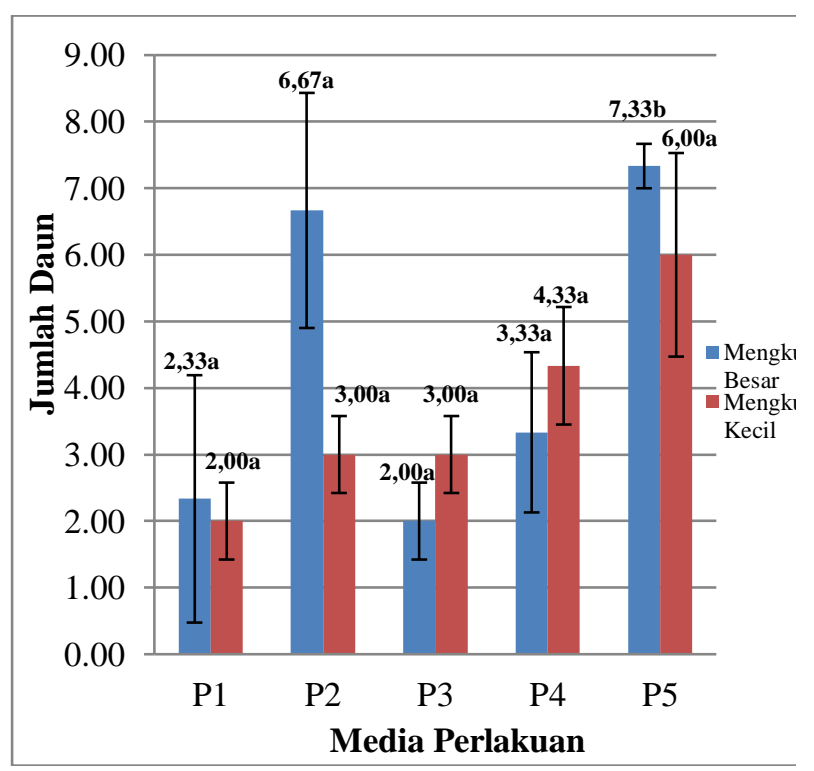

Gambar 4. Grafik rata-rata jumlah akar dua tipe mengkudu. Angka diikuti dengan huruf yang menunjukan hasil Uji BNJ pada taraf 5\%.

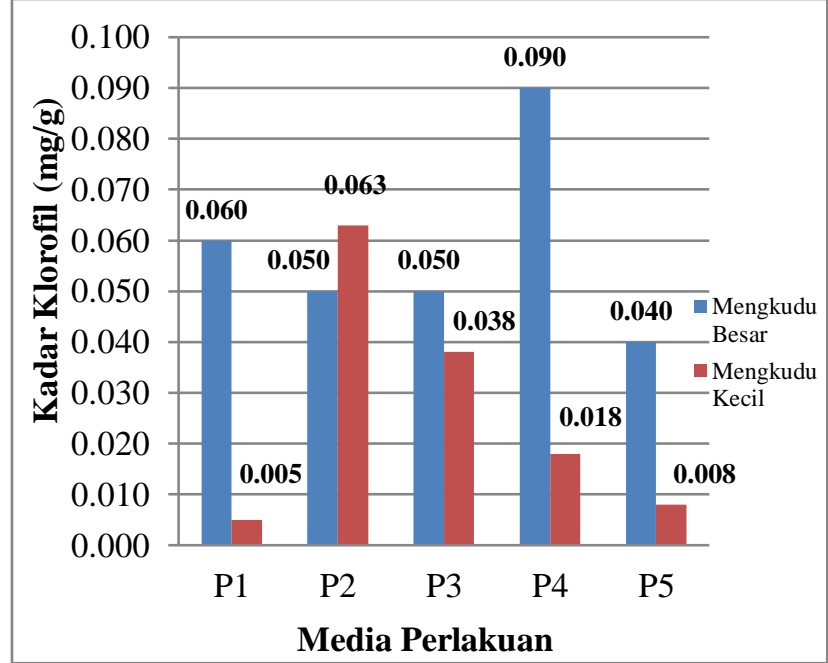

Gambar 5. Grafik rata-rata jumlah klorofil pada dua tipe daun mengkudu.

Penggunaan media dengan komposisi auksin dan sitokinin pada media $\mathrm{P} 2\left(\mathrm{MS}_{0}+\right.$ 0,05 ppm IAA + 0,3 ppm BAP) untuk tahap pembentukan tajuk dan pada media P5 $\left(\mathrm{MS}_{0}+0,9\right.$ ppm IAA $+0,3$ ppm BAP $)$ untuk tahap pembentukan akar, kemungkinan telah terjadi keseimbangan antara sitokinin-auksin yang ditambahkan dan yang diproduksi oleh tanaman mengkudu tersebut secara endogen, sehingga terjadi pembelahan sel yang menstimulasi pembentukan tunas dan akar tanaman mengkudu. Hal ini sesuai dengan pendapat Gunawan (1988), bahwa interaksi dan keseimbangan zat pengatur tumbuh yang ditambahkan dalam media dan yang diproduksi oleh sel tanaman secara endogen menentukan kecepatan dan arah perkembangan suatu kultur.

Parameter lain yang diamati pada penelitian ini yaitu kadar klorofil, setelah dikultur selama 4 minggu. Hasil 
pengukuran kadar klorofil dari daun Mengkudu besar menunjukkan bahwa eksplan pada media perlakuan P4 memiliki kadar klorofil yang lebih tinggi dibandingkan dengan media yang lain, sedangkan kadar klorofil terendah terdapat pada media perlakuan P5. Hasil pengukuran kadar klorofil pada daun mengkudu kecil menunjukkan bahwa kadar klorofil tertinggi terdapat pada media perlakuan P2. Data ini menunjukkan bahwa eksplan telah mampu mensintesis klorofil dan siap untuk melakukan fotosintesis, jika telah dipindahkan pada tahap aklimatisasi, sedangkan media perlakuan yang memiliki kadar klorofil terendah terdapat pada media P1. Hal ini menunjukkan bahwa daun Mengkudu besar pada media perlakuan P4 dan daun Mengkudu kecil pada media perlakuan P2 dapat mengabsorpsi cahaya lebih banyak dibandingkan eksplan pada media yang lain. Menurut Susanto (2008), banyaknya intensitas cahaya yang diabsorpsi oleh daun pada tanaman bergantung dari banyaknya klorofil yang dimiliki oleh daun pada tanaman tersebut. Semakin tinggi kandungan klorofil yang dimiliki oleh suatu tanaman, maka semakin baik pula aktivitas fotosintesis dan metabolisme pada tanaman tersebut.

Kombinasi konsentrasi zat pengatur tumbuh yang baik untuk induksi tajuk (daun) mengkudu besar dan mengkudu kecil yaitu media $\mathrm{P} 2\left(\mathrm{MS}_{0}+0,05 \mathrm{ppm}\right.$ IAA $+0,3$ ppm BAP), sedangkan media perlakuan yang paling baik untuk induksi akar yaitu media P5 $\left(\mathrm{MS}_{0}+0,9\right.$ ppm IAA + 0,3 ppm BAP).

\section{UCAPAN TERIMA KASIH}

Pada kesempatan ini penulis mengucapkan terima kasih kepada Ibu Sami Bukang S.Pt, dan Sdri Nurul Aisyah S.Si, laboran di Lab. Biotekhnologi FMIPA, juga kepada Ibu Waeniati S.Hut., M.Hut., dan Kak Haliani, S.P, Laboran di laboran Kultur Jaringan Fakultas Kehutanan UNTAD. Terima kasih juga penulis ucapkan kepada Kak Kadek Fena Armila S.P., dan Mira Robbiah, yang telah membantu selama penelitian di Lab.

\section{DAFTAR PUSTAKA}

Altman, A., And Loberant, B., 1998, Micropropagation : Clonal Plant Propagation In Vitro, p.19-42. In Arie Altman (Ed). In Agricultural Biotechnology, Marcel Dekker Inc, New York.

Anggraeni, S., Kusdianti, dan Kartikasari, D., 2007, Kandungan Metabolit Sekunder Dalam Kalus Mengkudu (Morinda citrifolia), Skripsi, Universitas Pendidikan Indonesia.

Ayabe, M., and Sumi, S., 1998, Estabilishment of a Novel Tissue Culture Methods, Stem Disc Culture and Its Practical Application to Micropropagation of Galic (Allium sativvum L.), Plant cell. Rep 17:773779. 
Bangun, A.P., dan Sarwono, B., 2002, Khasiat \& Manfaat Mengkudu, Agro Media, Tangerang.

Djauhariya, E., dan Rosman, R., 2001, Status Perkembangan Teknologi Tanaman Mengkudu, Balai Penelitian Tanaman Obat dan Aromatik, 13-29.

Djauhariya, E., Rahardjo, M., dan Ma'mun, 2006, Karakterisasi Morfologi dan Mutu Buah Mengkudu, Badan Litbang Pertanian, Dep. Pertanian 12 (1) : 1-8.

Gunawan, L.W., 1992, Teknik Kultur Jaringan Tumbuhan, Departemen Pendidikan dan Kebudayaan, Direktorat Jenderal Pendidikan Tinggi Pusat Antar Universitas Bioteknologi, Institut Pertanian Bogor, Bogor, hal. 165.

Gunawan, L.W., 1988, Teknik Kultur Jaringan Tumbuhan, Pusat Antar Universitas (PAU) Institut Pertanian Bogor, Bogor.

Harliana, Weaniati, Muslimin, dan Suwastika, I.N., 2012, Organogenesis Tanaman Jeruk Keprok (Citrus nobilis Lour.) Secara In Vitro Pada Media MS Dengan Penambahan berbagai Konsentrasi IAA (Indole Acetid Acid) Dan BAP (Benzyl Amino Purin), Jurnal Natural Science, 1 (1) : 34-42.

Hartmann, H. T., D. E. Kester, F. T., Davies Jr., And R. L., Geneve, 1997, Plant Propagation Principles And Practices Sixth Edition, Prentice Hall Inc, New Jersey.

Radji, M., 2005, Peranan Bioteknologi dan Mikroba Endofit dalam Mengembangkan Obat Herbal, J. Majalah Ilmu Kefarmasian 3 : 113 126.
Solomon, 1999, The Noni Phenomenon, Direct Source Publishing, Utah, USA.

Susanto, A., 2008, Kadar Klorofil pada Berbagai Tanaman yang Berbeda Umur, Skripsi, Fakultas MIPA Universitas Negeri Surabaya, Surabaya.

Tajuddin, R., Suwastika, I.N., dan Muslimin, 2012, Organogenesis Tanaman Anggur Hijau (Vitis vinifera L.) Pada Medium MS Dengan Penambahan IAA (Indole Acetid Acid) dan Berbagai Konsentrasi BAP (Benzil Amino Purin), Jurnal Natural Science, 1(1) : 63-73. 